\title{
Impacts of sex ratio reduction on male aggression in the Critically Endangered Hawaiian monk seal Monachus schauinslandi
}

\author{
Thea C. Johanos ${ }^{1, *}$, Brenda L. Becker ${ }^{1}$, Jason D. Baker ${ }^{1}$, Timothy J. Ragen ${ }^{2}$, \\ William G. Gilmartin ${ }^{3}$, Tim Gerrodette ${ }^{4}$ \\ ${ }^{1}$ NOAA Fisheries, Pacific Islands Fisheries Science Center, 1601 Kapiolani Blvd, Honolulu, Hawaii 96814, USA \\ ${ }^{2}$ Marine Mammal Commission, 4340 East-West Highway, Bethesda, Maryland 20814, USA \\ ${ }^{3}$ Hawaii Wildlife Fund, PO Box 70, Volcano, Hawaii 96785, USA \\ ${ }^{4}$ NOAA Fisheries, Southwest Fisheries Science Center, 8604 La Jolla Shores Drive, La Jolla, California 92037, USA
}

\begin{abstract}
High female mortality due to male aggression in Hawaiian monk seals led us to investigate the role of habitat use and social structure on sex ratios and aggression at Laysan Island, Hawaii. The sex ratio was strongly skewed towards males in the early 1980s and this, combined with the social structure, asynchronous reproduction, and terrestrial habitat use patterns, resulted in dramatic sex ratio imbalances in particular areas. Male:female ratios approached 1:1 in the northeast, whereas the overall ratio in the southwest was 5:1 ranging up to 25:1. Most of the aggressive incidents were observed in the southwest and females using this area were more likely to incur injuries. To reduce aggression, we selectively removed 37 males between 1984 and 1994, bringing the adult sex ratio to parity. Here, we evaluate the effect of this correction on aggression and female mortality. Before the removals, aggression accounted for an average annual mortality of adult females of $4.1 \%$ (range 0 to $12.9 \%$ ), with up to 8 females being killed per year. The male removals, together with natural processes, decreased the absolute sex ratio from 2.1:1 in 1983 to 0.9:1 in 1994. Both the proportion and the absolute number of injuries and deaths declined after this date. Although some adult females still incurred severe mounting injuries, the proportion of females that were lost decreased to $0.3 \% \mathrm{yr}^{-1}$ (range 0 to $2.6 \%$ ), and only 3 females are believed to have been killed through 2005. Thus, sex ratio reduction through selective male removals proved to be a valuable tool in reducing mortality in this Critically Endangered species.
\end{abstract}

KEY WORDS: Sex ratio $\cdot$ Male aggression $\cdot$ Mating injuries $\cdot$ Female survival $\cdot$ Hawaiian monk seal

\section{INTRODUCTION}

The second largest subpopulation of the Critically Endangered Hawaiian monk seal Monachus schauinslandi (IUCN 2010) occurs at Laysan Island ( $25^{\circ} 42^{\prime} \mathrm{N}$, $\left.171^{\circ} 44^{\prime} \mathrm{W}\right)$ in the Northwestern Hawaiian Islands (NWHI). Beach counts of monk seals at this site are currently about a third of their historical maximum recorded in 1958 (National Marine Fisheries Service 2007). These counts, which are used as an index of abundance, declined steadily from the late 1950s to the early 1980s, and subsequent counts and population totals suggested a continuing downward trend when our study began in 1983. At that time, the Laysan Island subpopulation (hereafter referred to as 'the population') included more than twice as many males as females, and the decline appeared to be partly due to adult female mortality resulting from male aggression during mating (Hiruki et al. 1993b).

The cause of the skewed absolute or population-wide sex ratio that was observed at Laysan Island in the early 1980s is unknown. Although earlier absolute sex ratios 
are unavailable because the population was not enumerated, researchers estimated that males outnumbered females (roughly 2 to 3:1) in 1978-1979 (Johnson \& Johnson 1981b). Baker \& Thompson (2007) found that survival of male and female pups born at Laysan Island since the early 1980s did not differ as they matured. However, the skewed ratio in the early 1980s might have been the result of differential mortality in the past. Laysan Island experienced an unusual die-off in the spring of 1978, when > 50 identified seals died or disappeared, and similar events might have previously occurred. The evidence was not sufficient to determine if males and females experienced differential mortality during the 1978 die-off, but preliminary analysis of tooth sections indicated that both very young and old seals were disproportionately affected (Gilmartin et al. 1980, Johnson \& Johnson 1981a, 1984). If older males are more likely to be dominant, the 1978 event might have destabilized the social structure at Laysan Island and contributed to increased male aggression and female mortality. Alternately, unequal sex ratios may simply be the result of the stochasticity experienced by small populations.

Little is known about the mating system of the endangered Hawaiian monk seal Monachus schauinslandi. Mating is aquatic, and minor dorsal scratches are often inflicted by males during normal mating as they hold onto females with foreflippers and teeth (Johanos et al. 1994). These injuries are usually observed after females wean their pups, go to the sea to forage, and return to shore, typically attended or accompanied by a male that actively guards her and prevents other males from accessing her. Both mating injuries and male attendance decrease as females approach molt, 2 mo post weaning (Johanos et al. 1994).

Hawaiian monk seals have an extended breeding season. Although births have been recorded in all months of the year, $80 \%$ of all pups are born between late February and early June at Laysan Island, and $80 \%$ of all mating injuries occur between mid-April and mid-July, after these females wean their pups and before they molt (Johanos et al. 1994). The lack of breeding synchrony in monk seals suggests that only a small proportion of females are near estrus and are available for mating at any one time. At Laysan Island, adult females use preferred pupping and nursing areas (Westlake \& Gilmartin 1990) but change their hauling locations after weaning their pup (Johnson \& Johnson 1984, Boness et al. 1998). These distribution pat- terns, along with those of breeding males, compound the effects of an imbalance in the absolute sex ratio and low availability of estrous females, thereby creating 'functional' sex ratios (sex ratios in a particular area and time) that may be highly skewed towards adult males and may increase the likelihood of aggression.

In some cases, multiple males simultaneously or consecutively attempt to mount and mate with a single seal over an extended period (Johanos et al. 1994; Fig. 1A), causing midline back wounds ranging from densely bite-punctured skin to large deeply eroded areas exposing muscle tissue (Hiruki et al. 1993a; Fig. 1B). Although immature seals of either sex may be attacked (Wirtz 1968, Johnson \& Johnson 1978, Hiruki et al. 1993a), the vast majority of mounting injuries were observed on adult females (Hiruki et al. 1993a), and postmortem examination of fatally injured females revealed that most were in estrus when initially attacked (Atkinson et al. 1994). Severe mounting injuries were first described for monk seals at Kure Atoll in the mid-1960s (Wirtz 1968). Scars that are typ-
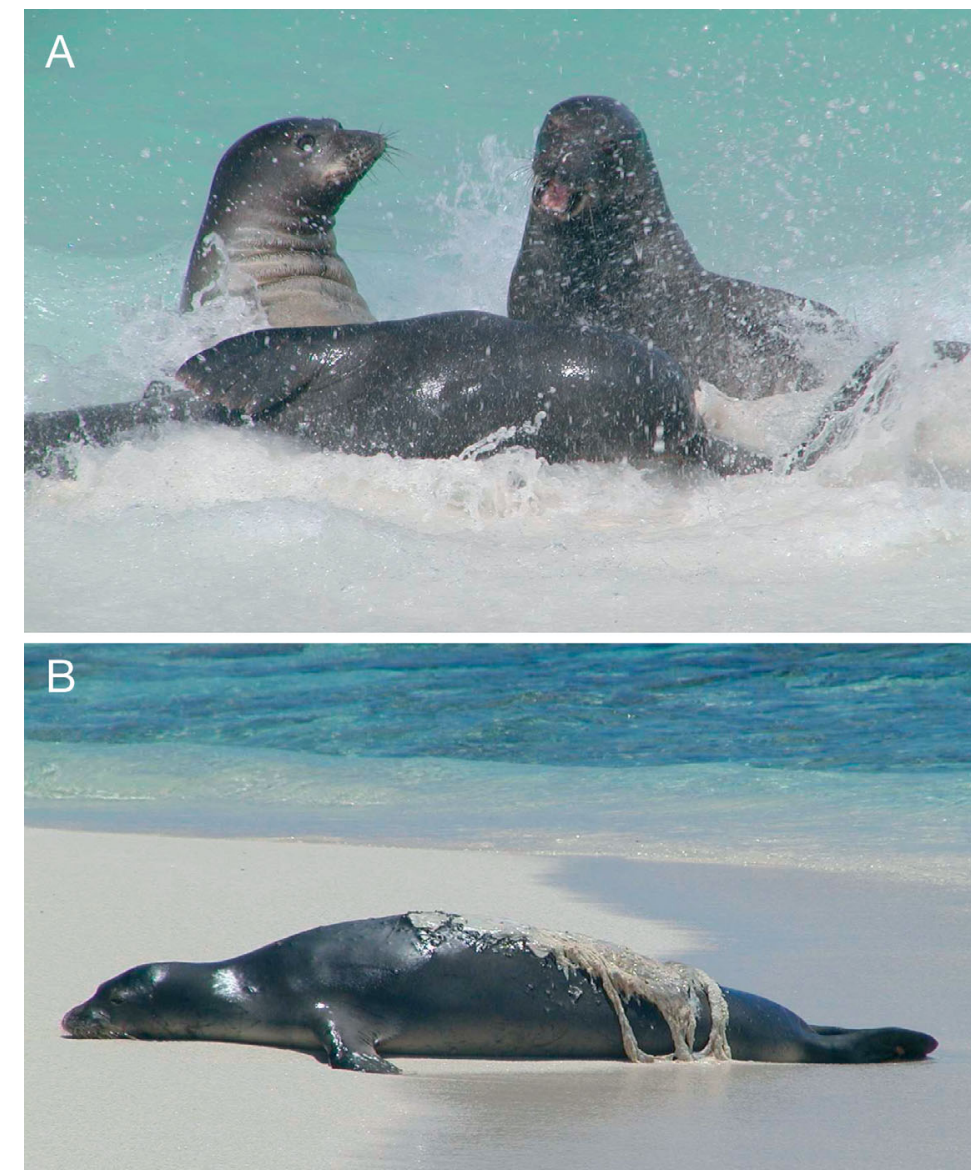

Fig. 1. Monachus schauinslandi. (A) Incident of multiple male Hawaiian monk seal aggression. (B) Adult female seal with severe mounting injuries. Photos by (A) M. Yannacone and (B) K. Holman of NOAA Fisheries, Pacific Islands Fisheries Science Center 
ical of mounting injuries were observed at Laysan Island in 1977, and the first documented attack was observed there in 1978 (Johnson \& Johnson 1978, 1981a). Aggressive aggregations lasted from a few minutes to $>8 \mathrm{~h}$, with the number of males involved ranging from 2 to 32 (Johnson \& Johnson 1981a, Alcorn 1984, Johanos \& Kam 1986, Johanos et al. 1987, Johanos \& Austin 1988, Alcorn \& Buelna 1989, Johanos et al. 1990). Most such events occurred at sea, and witnessed incidents represented only a small fraction of the total based on observed injuries. The major population effect was increased female mortality; severe mounting injuries were the most frequently observed cause of traumatic death at Laysan Island, and 87.5\% ( $n=16$ ) of the adult females that were known to have died between 1983 and 1989 sustained injuries from adult males (Banish \& Gilmartin 1992, Hiruki et al. 1993b). In addition, survival decreased for pups of females that were injured by males shortly before parturition or during lactation.

The mortality of adult females resulting from adult male aggression has serious consequences, especially for an endangered species, due to the loss of both the female and her entire future reproductive potential. Because severe mounting injuries have been seen most frequently at locations with male-biased sex ratios (Hiruki et al. 1993b), the imbalance may lead to more male aggression. Starfield et al. (1995) modeled the relationship between male aggression and a population's sex ratio to evaluate the probable effects of alternative management strategies. Their results supported immediate removal of males from the populations where such aggression occurs. Although the exact relationship between sex ratio and male aggression was unknown, their conclusions were generally robust to variations in this potential relationship. Additional modeling estimates indicated that sex ratios at Laysan Island would not achieve equilibrium naturally for at least a decade (Gilmartin \& Eberhardt 1995). To prevent or reduce male aggression and female mortality during this period, the National Marine Fisheries Service (NMFS) removed a number of males, decreasing the absolute adult sex ratio - the ratio within the entire population. The present paper reviews the efficacy of those actions, and whether they reduced female mortality, based on $23 \mathrm{yr}$ of data on male aggression and other population parameters.

\section{MATERIALS AND METHODS}

Research camps of 3 to 9 mo duration were established annually on Laysan Island during the spring-summer months of 1983-2005 to identify and mitigate, where possible, factors impeding species recovery. Field seasons were scheduled to coincide with the height of the breeding season and covered as much of the year as feasible, given logistical and budgetary constraints. Data were collected with a consistency in effort and basic methodology throughout this period. The $11 \mathrm{~km}$ perimeter of Laysan Island was divided into 20 areas, or sectors, using natural or artificial landmarks to describe the spatial properties in the habitat use patterns of individuals (Fig. 2). The entire perimeter was usually monitored daily to (1) identify individual seals, (2) document births,
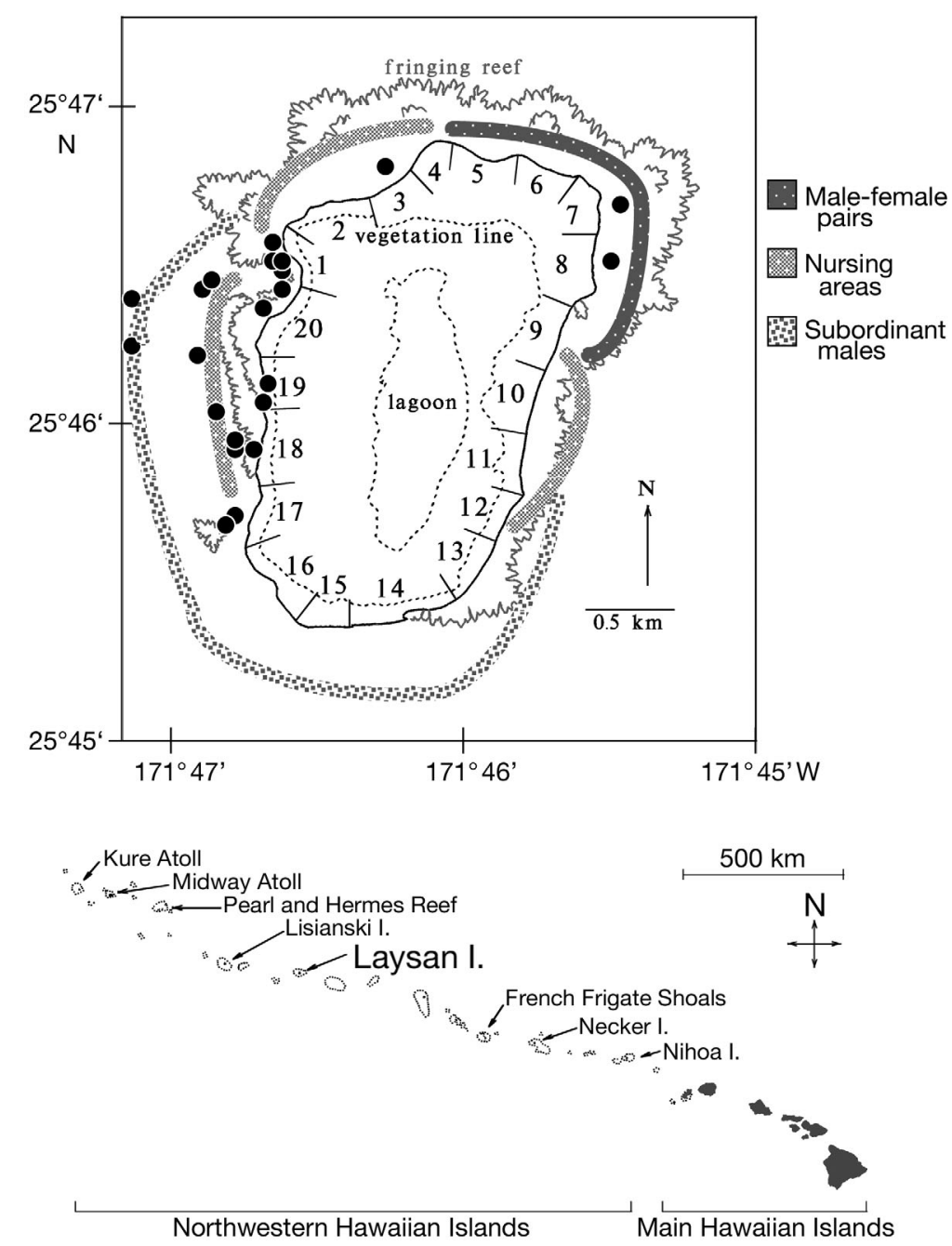

Fig. 2. Laysan Island showing sector locations and the island location within the Northwestern Hawaiian Islands. Generalized beach use patterns of Hawaiian monk seals are depicted by group. (•) Observed incidents of multiple male aggression at Laysan Island, 1978-2005 (n = 22). Adult and large subadult females were targeted in 20 of these events, and subadult males were targeted in the remaining two 
weaning, and molting, and (3) document adult male aggression, mounting injuries, and deaths. Daily monitoring used a variety of survey types that included, but were not limited to, the standard surveys described below. Attention was directed out to sea as much as possible because aggressive aggregations have been observed most frequently in water.

Population composition and absolute sex ratios. Over the course of the field season, researchers individually identified all, or almost all, seals in the Laysan Island population each year by a combination of tags, scars, and natural or applied marks (Baker et al. 2006, Harting et al. 2007). In most years, sufficient data were collected to completely enumerate the population and estimate, among other things, abundance and age group composition (Baker et al. 2006). In these years, the absolute sex ratio was calculated as the number of adult-sized males divided by the number of adult-sized females in the population.

Beach counts and functional sex ratios. In all years, researchers collected data during whole-island surveys that were conducted every 2 to $4 \mathrm{~d}$. Data were collected on each seal and included size (adult, subadult, juvenile, or pup), sex, location, individual identification, reproductive status, molting status, and their associations, or spatial proximity and interactions with other seals. Additional sighting data that were collected in most years during similar surveys of the entire island perimeter only recorded all adult and large subadult males and their associations. Seals were classified as adults if they were reproductively active or were of the size of known breeders. For this study, large subadults, possibly immature but near adult size, were included in the adult male and female categories because the boundary between these size categories is subjective and is thus an imperfect indicator of sexual maturity. For some analyses, adult females were divided into 2 categories: nursing, if they were currently with a pup, and non-nursing for all other females. Survey data that were collected outside of our typical field season (March-August) were excluded. Data were further restricted for the analyses involving distribution patterns and functional sex ratios, which were calculated as the ratio of adult males to adult females that were sighted in an area under survey. For these analyses, data from the surveys documenting all seals were used, with seals in the water being excluded based on potential variations in observer detection rates. Data that were collected before April or after July were also excluded to reduce potential confounding effects of seasonal changes in behavior and habitat use patterns (e.g. males are less likely to attend to females, and may begin to molt in August). Data from both survey types, which were collected between March and August, were used to separate males into groups based on behavioral traits that are described below.

Classification of females as 'prime'. Male attendance of adult females peaks, and most mating injuries occur, after the females wean their pups and before they molt - an interval of $\sim 2$ mo (Johanos et al. 1994). Assuming that estrus occurs at least once during this interval, females were considered most valuable, or 'prime', from weaning or loss of pup until the onset of molting for parturient females, or during the 2 mo prior to molting for nonparturient adult females. Pupping and weaning dates were used in the calculations if the date was exactly known or within a range of $\leq 4 \mathrm{~d}$ (the midpoints of ranges were used). If not, pupping/weaning dates were estimated from a known date by adding $39 \mathrm{~d}$ (the average lactation period; Johanos et al. 1994) to the birth date or subtracting $39 \mathrm{~d}$ from the weaning date. Females were then defined as prime during the $60 \mathrm{~d}$ after weaning. If a female was not parturient in a particular year, her prime period for that year was estimated using $60 \mathrm{~d}$ prior to the onset of molting.

Classification of adult males as dominant or subordinate. Adult males compete with each other for the privilege of lying beside and controlling access to females, especially prime females (NMFS unpubl. data). For the purpose of this study, males were classified as dominant based on their observed association with females at or near estrus. In cases where both members of a male-female pair were identified and the female's reproductive history was known, males were scored by the number of survey days when they were observed within $5 \mathrm{~m}$ of a prime female. High ranking males were classified as dominant if they were in the group accounting for $50 \%$ of all observed pairings of adult males with identified prime females. The remaining males were placed in the subordinate category.

Documenting male aggression, injuries, deaths, and probable deaths. Researchers observed and documented male aggression and mounting injuries, deaths, and probable deaths. Mating-related aggression was defined as any incident where an adult or subadult male repeatedly bit the dorsum, attempted to mount, and tried to prevent the escape of another seal. As mentioned previously, incidents of multiple male aggression occurred when several males attempted to mount a single seal, usually an adult female or an immature seal of either sex, causing the injury or death of that seal (Johanos et al. 1994). Observed incidents were summarized if they simultaneously involved $>1$ male aggressor or resulted in at least one puncture or gaping wound extending into the blubber layer or involving missing skin, or $\geq 15$ scratches to the dorsum or flanks. Recorded information included island location; number, identities, behaviors, and roles of all seals involved; chronology of events; and outcome. 
Post-event aggregations were also summarized: these were groups of males that were congregated on the beach and attending a seal with new mounting injuries as described above. Mounting injuries from unobserved incidents were distinguished from other causes of injury based on characteristic abrasions or gaping wounds on the dorsum of the injured seal, which occasionally extended to its flanks (Hiruki et al. 1993a). Although minor injuries may be associated with normal mating activity (Johanos et al. 1994), injuries were considered severe enough to possibly affect survival and were summarized if (1) densely spaced overlapping scratches, abrasions, or lacerations covered an area equivalent to half the dorsum or there was evidence of extensive underlying tissue damage (e.g. an uneven or darkened surface of the injured area, leaching fluids, or impaired seal movement), or (2) the total combined area of abscesses or exposed area of gaping wounds was $\geq 8 \mathrm{~cm}$ in diameter. The cause of death was attributed to male aggression if a seal died due to injuries sustained. In addition to known deaths, a seal was considered probably dead if it sustained severe injuries and appeared lethargic, in deteriorating condition, or near death prior to disappearance. Deaths and probable deaths were combined in the analyses. All aggressions, injuries, deaths, and probable deaths were documented from March to August (our normal field season), with the exception of a single serious injury that was documented in September 2002.

Male removals reducing the absolute sex ratio. Over a 10 yr period, a total of 37 adult males (of $\sim 115$ ) were removed from the Laysan Island population, reducing the adult sex ratio. These removals occurred in 3 phases: 10 seals were captured in 1984 (9 were released at Johnston Atoll, located 550 nautical miles southwest of Laysan Island, and 1 died in captivity), 5 seals were brought into permanent captivity in 1987 , and 22 were captured in 1994 (21 were released in the main Hawaiian Islands, and 1 died during capture).

Selection criteria for these removals varied over time. In 1984, all males that were selected for removal had either attacked or harassed victims during observed events $(n=9)$, or exhibited behaviors that were characteristic of males known to have been involved in such attacks $(\mathrm{n}=1)$. To characterize male aggressors, we used data from both Laysan Island and Lisianski Island, where similar problems were being observed and where the same research/monitoring strategy was being implemented. We identified 13 of 116 males as aggressors at Lisianski Island in 1983 and 16 of 105 males as aggressors at Laysan Island in 1984. These individuals showed signs of consistent aggressive behavior; 5 males were identified in repeated incidents within a single year, and 2 aggressive males in the Laysan sample were identified as aggressive during the previous season. Based on discriminant analysis of behavioral data collected during surveys, a set of 4 key variables that reliably separated aggressors from nonaggressors was found in both island/year sets: the proportion of sightings of a male that was observed to be 'cruising' or seeking females along the shoreline and the number of different sectors in which the seal was sighted were positively associated with aggressors, while the proportion of sightings of a male that was within $5 \mathrm{~m}$ of an adult female and the mean number of consecutive survey sightings were negatively associated with aggressors. Aggressor profiles were developed, and males were ranked according to their conformance with these profiles. The Laysan Island and Lisianski Island profiles had similar features and males that ranked high using one profile tended to rank high using the other (NMFS unpubl. data). Since close spatial association with adult females was a key negative indicator for aggressive males, subordinate males (those that rarely paired with females) conformed well to the aggressor profiles, whereas dominant males did not. Because we observed that aggressors tended to be subordinate males, and to minimize the risk of disrupting the social structure, dominant males were not selected for removal even if they had been observed in aggressive aggregations. Only subordinate males were targeted for removal in 1987 and 1994, with preference being given to those that were observed to exhibit aggressive behavior.

Analysis of demographic data. We compared the use of different island areas by dominant males, subordinate males, and nursing and non-nursing females during the period from April to July. Distribution patterns of males that were observed to be in aggressive aggregations, female targets of those attacks, and all females with moderate to severe mounting injuries were compared (for the year of attack or injury) with patterns observed in the general population. Functional sex ratios were calculated by sector and for 2 larger areas suggested by the data - the northeast area (Sectors 2-11) and the southwest area (Sectors 12-20 and Sector 1 ; Fig. 2). Incidents of observed male aggression were mapped and compared with these patterns.

Trends in absolute adult sex ratios were calculated in years when the entire population was enumerated. These ratios were evaluated for trends as the population composition changed and after adult males were removed. The effects of reducing absolute sex ratios were compared by year and between 2 periods (up to and including 1994, and after 1994). Although 1994 was the year of the largest and final adult male removal, 1994 data were included in the first period because all survey data in the analysis were collected prior to the first adult male capture on July 8. Functional sex ratios of seals that were on shore (adult 
males:all adult females; and adult males: non-nursing adult females) were calculated by sector and by area for each period. Injuries, deaths, and probable deaths were summarized, and presented as incidents per adult female per year.

\section{RESULTS}

\section{Classification of males as dominant or subordinate}

Males in the operant dominant category accounted for 10 to $20 \%$ of all adult males in the population each year. Thus, only a relatively small portion of the males at Laysan Island actively sought out, obtained, and defended access to females and accounted for the majority of observed pairings. The top male in a given year was seen to be paired with a prime female at an average of 15 survey days (range 6 to 30 survey days). Data from 1983, 1986, 1987, and 2005 were excluded based on the small sample size of sightings of identified males with prime females $(n<50)$ in these years.

\section{Differential haul-out patterns by area}

Nursing and non-nursing females, and all males were non-uniformly distributed among island sectors (Fig. 3). Deviations from uniformity were highly significant, both before and after the male removals (6 tests for uniformity among sectors ranged from $\chi^{2}=2142.2,19 \mathrm{df}, \mathrm{p} \ll 0.001$ to $\left.\chi^{2}=17204.6,19 \mathrm{df}, \mathrm{p}<<0.001\right)$. Distribution patterns also differed among groups (Figs. 2 \& 3). Pupping occurred primarily in the west, northwest, and east, which are areas with sheltering reefs and calmer waters. After weaning their pups, females left the pupping areas and preferentially hauled out on the northeastern side of the island among other non-nursing females. By definition, the distribution of dominant males tended to mirror that of post-parturient females: $75.4 \%$ of sightings of dominant males were on the northeastern side of the island. Nondominant males had a more generalized distribution pattern, commonly using both the northeast and southwest beaches (with $50 \%$ of sightings in each area).

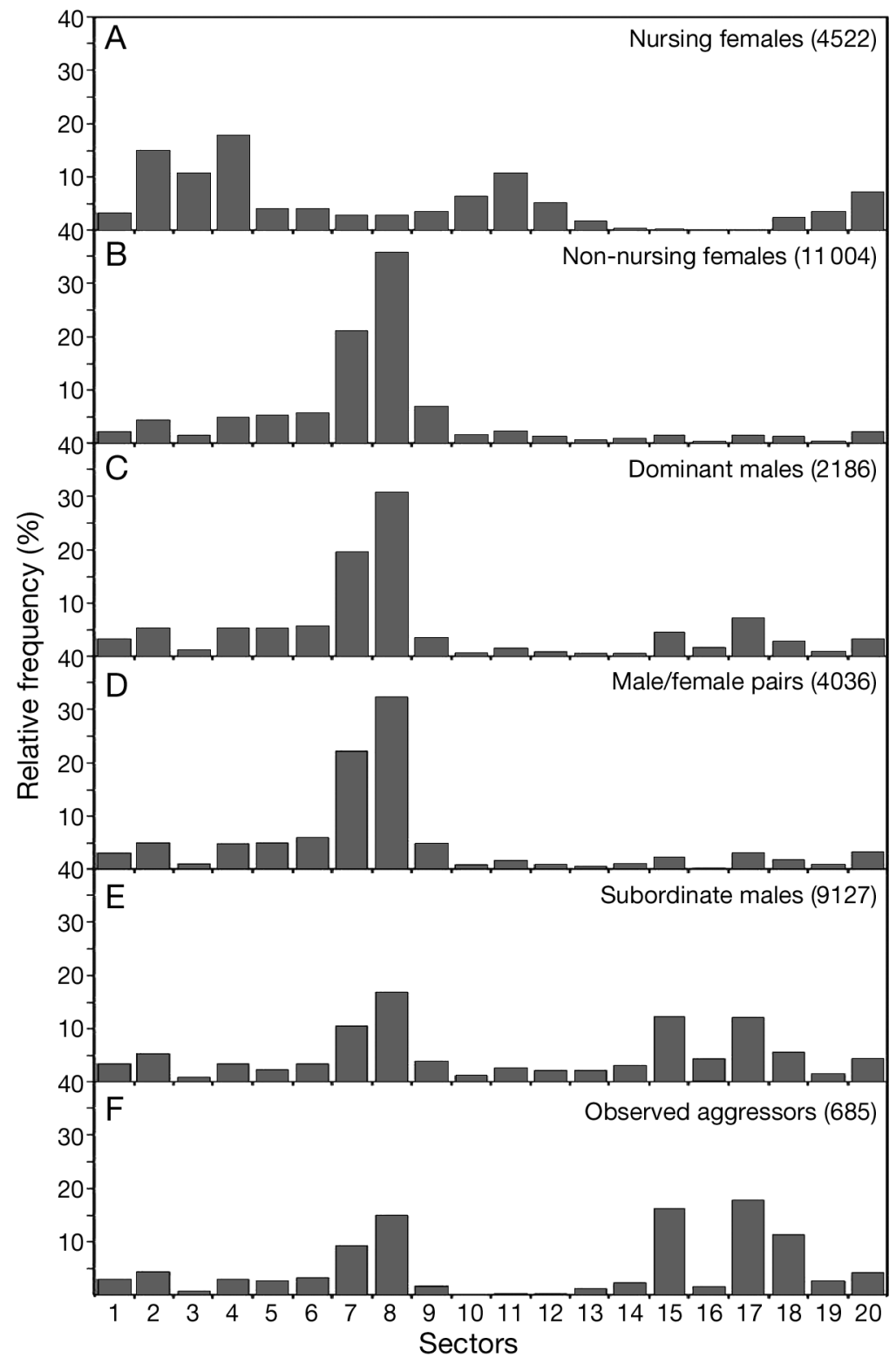

Fig. 3. Monachus schauinslandi. Non-uniform distribution patterns of adults at Laysan Island by sector (see Fig. 2), presented as percentages of survey sightings during April through July 1983-2005. Sample sizes are in parentheses. (A) Nursing females, (B) non-nursing females, (C) dominant males, (D) male-female pairs, (E) subordinate males, and (F) observed aggressors in the year they attacked. See Fig. 2 for sectors

\section{Functional sex ratios and male aggression by area}

The sex ratio of adult males to non-nursing adult females and the incidence of aggression varied widely around Laysan Island. Combining all years, the functional sex ratio was near unity $(0.9: 1)$ in the northeast. In contrast, the ratio was highly biased towards males in the southwest (Fig. 4); the overall ratio was 5:1, ranging up as high as 25:1. Further, the proportion of identified males that were dominant was over twice as high in the 


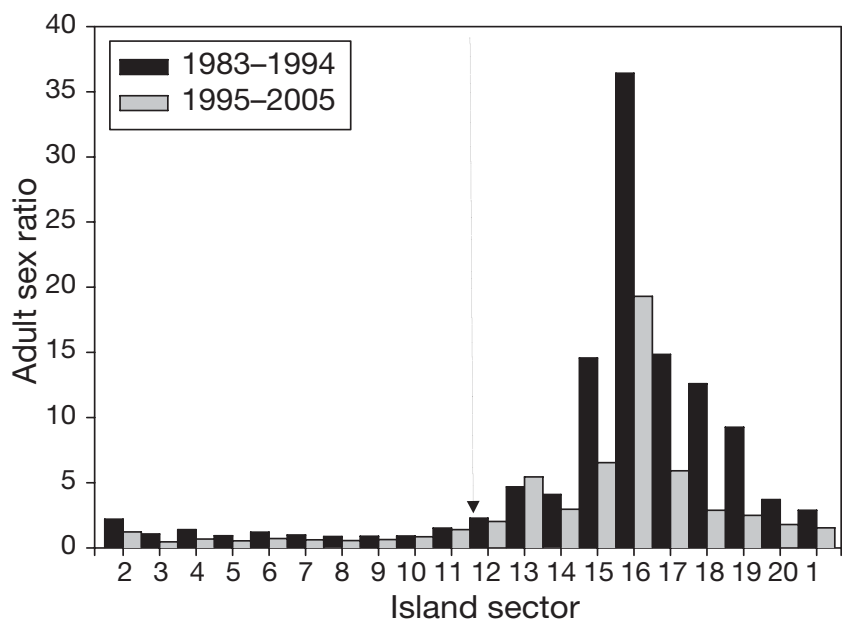

Fig. 4. Monachus schauinslandi. Functional adult sex ratios observed at Laysan Island by sector, before and after the final adult male removal. Sex ratios are expressed as adult males to non-nursing adult females observed during surveys in April through July. The arrow divides the sectors into 2 larger groupings suggested by the data - northeast (Sectors 2-11) and southwest (Sectors 12-20,1). See Fig. 2 for sectors

northeast $(27.2 \%)$ as in the southwest $(10.8 \%)$. Observed aggressors hauled out in both the northeast and southwest, displaying a typical nondominant pattern (Fig. 3E,F). The distribution of females that were ultimately attacked during observed events or injured during unobserved events differed from those of other adult females. These females tended to haul out more frequently on southwest beaches where the sex ratio was highly skewed $\left(\chi^{2}=45.1,1 \mathrm{df}, \mathrm{p}<0.001\right.$ and $\chi^{2}=36.7$, $1 \mathrm{df}, \mathrm{p}<0.001$, respectively). The distribution of observed multiple male attacks suggests a similar pattern, although these results were biased by greater observation in the area of the research camp, which was located on the west side of the island in sectors 1 and 20. In all, 22 incidents were observed: 20 during our study and 2 earlier, with adult or large subadult females being targeted in 20 events and subadult males being targeted in 2. Most aggressive aggregations (19 of 22) were observed on the west side (in sectors 17-20, 1), where the sex ratio was higher and where pupping and nondominant haul-out areas largely overlapped (Figs. 2 \& 3).

\section{Male removal and absolute sex ratio reduction}

The removal of 37 males between 1984 and 1994, together with natural processes, decreased the absolute adult sex ratio from 2.1:1 in 1983 to 0.9:1 in 1994 (after the final removal); it has since remained low (Fig. 5A). The sex ratio of pups born during the study was $\sim 1: 1$ at birth (405 males:420 females) and remained fairly even as these seals matured, causing a gradual natural de-
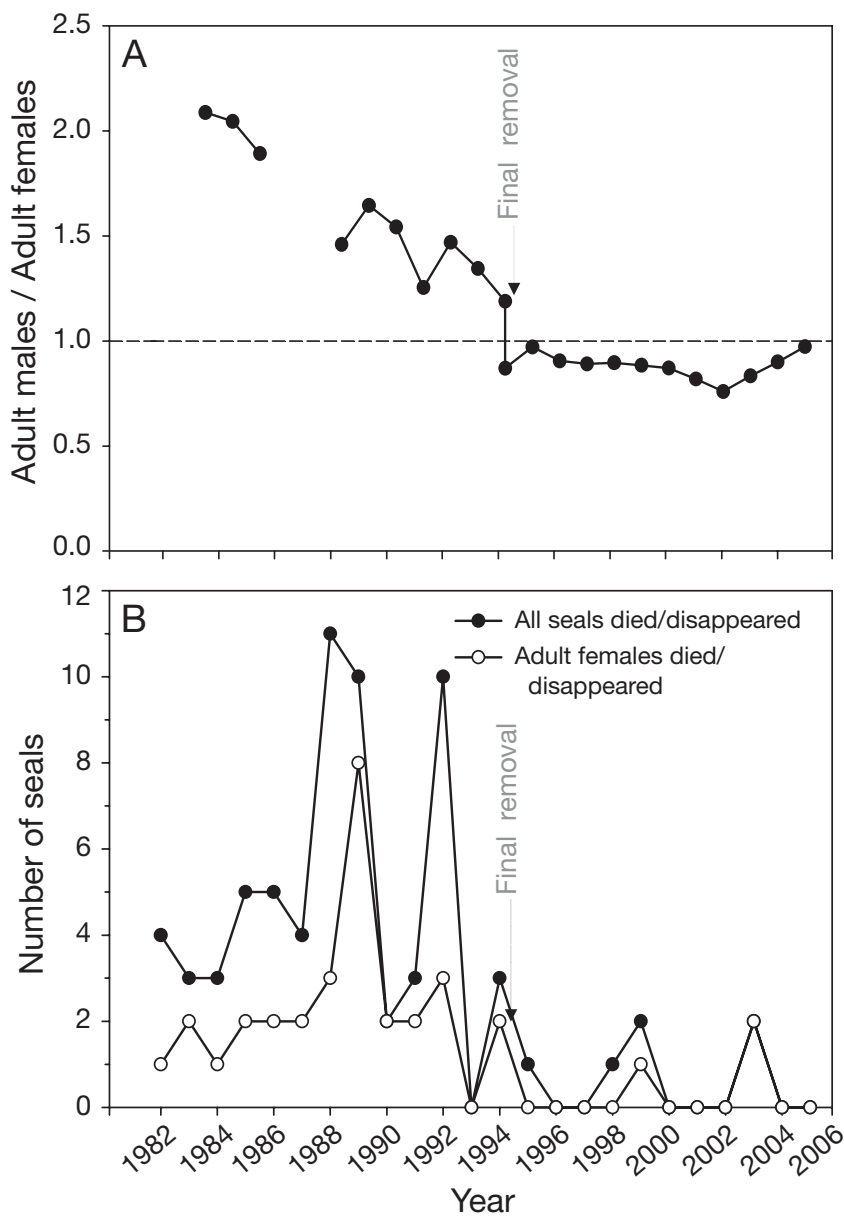

Fig. 5. Monachus schauinslandi. Absolute or population adult sex ratios, and seal deaths and disappearances due to male aggression at Laysan Island, by year. (A) Absolute adult sex ratio at Laysan Island from 1983 to 2005 . The 2 data points for 1994 depict the sex ratio of the population before and after the final male removal. (B) Numbers of all seals and all adult females that died or disappeared from 1982 to 2005. Arrows: timing of the final adult male removal, which occurred after the 1994 field season

cline in the absolute sex ratio as younger animals replaced older ones, which augmented the sex ratio reduction due to male removals. None of the males that were removed have returned to Laysan Island.

\section{Functional sex ratios by area before and after male removals}

After male removals, the proportion of males to nonnursing females was lower than it was before the removals in both the southwest $\left(\chi^{2}=156.9,1 \mathrm{df}, \mathrm{p}<<\right.$ 0.001 ) and northeast $\left(\chi^{2}=205,1 \mathrm{df}, \mathrm{p}<<0.001\right)$ areas. However, the change was much more dramatic in the southwest (sectors 12-20,1) where most observed incidents of male aggression occurred (Fig. 4). 
Sex ratios were significantly higher in the southwest than in the northeast area both before and after the removals. This pattern has persisted both for the ratio of males to all females $\left(\chi^{2}=1847.0,1 \mathrm{df}, \mathrm{p}<0.001\right.$ before, and $\chi^{2}=626.6,1 \mathrm{df}, \mathrm{p}<0.001$ after) and the ratio of males to non-nursing females $\left(\chi^{2}=2056.0,1 \mathrm{df}\right.$, $\mathrm{p}<0.001$ before, and $\chi^{2}=768.8,1 \mathrm{df}, \mathrm{p}<0.001$ after).

\section{Evidence of aggression before and after male removals}

Evidence of male aggression, as measured by the proportion of adult females injured and killed, declined after the male removals $\left(\chi^{2}=44.7,1 \mathrm{df}, \mathrm{p}<0.001\right.$ and $\chi^{2}=24.7,1 \mathrm{df}, \mathrm{p}<<0.001$, respectively). Prior to the final adult male removal (1983-1994), an average of $4.1 \%$ (range 0 to $12.9 \%$ ) of all adult females died/disappeared each year because of mounting injuries, and an additional $10.9 \%$ (range 0 to $21 \%$ ) received moderate to severe mounting injuries yet survived. In the year of highest aggression (1989), 8 females were lost and an additional 13 were moderately to severely injured, both values representing $33.9 \%$ of all adult females $(n=62)$. The proportion of adult females that were killed decreased to an average of only $0.3 \%$ (range 0 to $2.6 \%$ ) each year after the final removal (1995-2005), and only 3 adult female deaths/probable deaths were attributable to adult male aggression (1 in 1999, 2 in 2003, Fig. 5B). Although females still incurred major mounting injuries after the removals, the proportion of adult females that were injured also decreased (to an average of $2.3 \% \mathrm{yr}^{-1}$, range 0 to $6.8 \%$ ). Mounting injuries and deaths for all size and sex classes of seals followed a similar pattern, and also fell after the final male removals $\left(\chi^{2}=55.7,1 \mathrm{df}, \mathrm{p}<0.001\right.$ and $\chi^{2}=39.2,1 \mathrm{df}$, $\mathrm{p}<<0.001$, respectively). With comparable observation effort in most years, observed incidents of multiple male aggression declined from $1.5 \mathrm{yr}^{-1}$ during the first period $\left(\mathrm{n}=18\right.$ ) to $0.2 \mathrm{yr}^{-1}$ during the second period $(\mathrm{n}=$ 2). The most recent observed incident occurred in 1996.

\section{DISCUSSION}

The sex ratio of the Laysan Island monk seal population was heavily skewed toward males, and an ongoing population decline appeared to be partly due to the loss of females to male aggression when our study began. This adult sex ratio was declining naturally from the early 1980s and selective removal of subordinate males, giving preference to aggressors, accelerated this natural trend with the goal of reducing female mortality, bringing the absolute sex ratio to or below unity and reducing the functional sex ratio in all areas.
For polygynous species, functional sex ratios vary widely at breeding sites. At Seal Lion Island in the Falkland Islands, the southern elephant seal breeding sex ratio is strongly imbalanced, with $\sim 14$ females per breeding male on average, and up to 47 females per territory-holding male during peak haul-out (Galimberti \& Boitani 1999). Thus, at a given location, functional sex ratios may fluctuate and even reverse over time; grey seal sex ratios on Sable Island, Nova Scotia, reverse from 2 to 4 females male ${ }^{-1}$ early in the pupping period to 1 female to 2 males late in the pupping period (Boness et al. 1995). Moreover, at a given time, functional sex ratios may also fluctuate and reverse spatially; northern elephant seal sex ratios are strongly female biased within the core breeding area, but sex ratios of 4 to 25 males female ${ }^{-1}$ have been recorded on the periphery (Le Boeuf \& Mesnick 1991). Likewise, we found that Hawaiian monk seals are not distributed uniformly and that functional sex ratios vary widely by area at Laysan Island. Combining all years, the functional sex ratios are slightly female biased in the northeast, where male-female pairs predominate, but reverse spatially in the southwest where the overall ratio is male biased and reaches as high as 25 males female ${ }^{-1}$.

Male aggression towards adult females resulting in mating injuries or death has been observed in many species, and sex ratios have been linked to aggression and population viability. In lizards, an excess of males resulted in increased aggression towards females and decreased female survival and fecundity, thereby causing a major risk of population extinction (Le Galliard et al. 2005). Highly male-biased sex ratios were suggested as a major factor limiting population growth in endangered buntings (Steifetten \& Dale 2006). In pinnipeds, functional sex ratios have been linked to the rate of male harassment in southern elephant seals (Galimberti et al. 2000) and grey seals (Boness et al. 1995) and to the number of fatal injuries inflicted by males in northern elephant seals (Le Boeuf \& Mesnick 1991). For monk seals, high functional sex ratios were also linked to greater risk of adult female injury and death.

Reproductive synchrony reduces the functional sex ratio and may thus reduce the risk of male aggression in many species. Boness et al. (1995) proposed that male harassment of females contributes to reproductive synchrony in grey seals by affecting maternal performance. For northern elephant seals, the probability of a female being killed by males during the breeding season is very low, and females are expected to evolve adaptations such as synchrony to reduce injurious encounters with males (Le Boeuf \& Mesnick 1991). In southern elephant seals, females breeding at the peak of the season suffered lower levels of harassment, 
whereas isolated females suffered more herding episodes and were approached more frequently by males (Galimberti et al. 2000). In contrast, Hawaiian monk seals have a protracted reproductive season. This lack of synchrony is probably related to the subtropical environment, which allows more flexibility and variability in the timing of pupping, estrus, and molting. With relatively few females in estrus at any given time, localized imbalances in the ratio of breeding males to available females are likely, and males are forced to continuously search out and compete for access to females, increasing the probability that an estrous female will be attacked.

The causes of male aggression in monk seals are unclear but may be mediated by the social structure. Theoretically, dominant males control access to the females with which they are paired, thus protecting them from multiple male aggression. A 'functional' failure of the social structure might occur if no males are able to exert their dominance, and females are subjected to the reproductive aggression of a number of competing males. A lack of social stability may lead to increased aggression (Linklater et al. 1999, McCowan et al. 2008), and for monk seals, the likelihood of male aggression (or social chaos) may increase if a sufficient number of clearly dominant males are not present. However, much of the evidence gathered to date suggests that aggressive incidents may be more likely to result from a 'numerical' failure, where a male that is capable of exerting dominance over 1 or 2 competing males is overwhelmed by a larger number of competitors and is unable to prevent their access to a female. At the onset of an aggressive onshore attack observed in 1985, an attending male defended a female from a succession of 4 male challengers that remained nearby. Eventually, one of the 'defeated' males made a second attempt, and as he fought the attending male, another male rushed in. The defending male rushed back towards the female, followed by all remaining males, and was quickly overwhelmed (Johanos \& Austin 1988). The potential for such loss of control is high for monk seals because they mate in water. Male pinnipeds can more easily control access to females on land or on ice, although control of access may be lost if a large enough group of males challenges a controlling male. Upon entering the water, however, the area to defend changes from a 2-dimensional to a 3-dimensional space, and repelling multiple competitors becomes increasingly difficult. Because both failures of the social structure are interconnected, the primary factor likely varies with each population. Although we do not know what triggers an aggressive aggregation, the probability may be increased by any factor that skews the functional sex ratio at a particular time and location. Such factors might include island geography, asynchronous reproduction, number of females with a pup (such females are harshly intolerant of other seals and are essentially unavailable to potential consorts; Johnson \& Johnson 1984, Johanos et al. 1994), and spatially selective distribution patterns which may lead to separation or, alternatively, concentration of males and females in particular geographic areas.

The absolute sex ratio of the population influences the functional sex ratio, but other factors also influence the latter. In this study, asynchronous events in the female reproductive cycle (pupping, estrus, and molting), along with haul-out behavior, resulted in nonuniform functional sex ratios around the island. Furthermore, when the absolute sex ratio was reduced, flexibility in haul-out behavior and the selection of subordinate males for removal led to a non-uniform response to this change in the 2 geographic areas. Males might have moved into available dominant roles in the northeast as opportunities presented themselves, maintaining fairly constant sex ratios in this area. In contrast, functional sex ratios in the southwest (the area occupied mostly by subordinate males where sex ratios and male aggression were highest) showed dramatic reductions. The intervention was successful; the absolute sex ratio has remained near unity since the final male removal and the functional sex ratio was also reduced in all areas, which likely improved the ability of dominant males to control access to females. Serious mounting injuries and deaths have been reduced, although they still occur at a low level. Because the loss of adult females (and their potential pups) inhibits future population growth, reducing these losses removed a barrier to population growth and positively benefited the Laysan Island population. Such intervention should not be undertaken lightly and, when conducted, should be followed up to evaluate success. In this case, removing males proved to be a valuable and effective tool for conserving this endangered species.

Acknowledgements. We thank the field crews who endured many long months under primitive, isolated conditions, particularly D. Alcorn, D. Dick, and K. Holman. Special thanks are extended to the volunteers who participated in all aspects of this work, especially R. Gaylord, L. Keith, J. Kermode, S. Minasian, and C. Vanderlip, who assisted in the capture and relocation of the adult males. G. Antonelis provided valuable insights, and M. Chapla and C. Littnan gave many helpful suggestions. The US Fish and Wildlife Service, Hawaiian Islands National Wildlife Refuge, and the captain, officers, and crew of the NOAA ships 'Townsend Cromwell' and 'Oscar Elton Sette' provided important logistical support. This research was conducted in accordance with institutional, national, and international guidelines concerning the use of animals in research and/or the sampling of endangered species and was authorized under the following NMFS Scientific Research and Enhancement Permits: 413, 482, 489, 889, 8481335, 848-1695. 


\section{LITERATURE CITED}

Alcorn DJ (1984) The Hawaiian monk seal on Laysan Island: 1982. US Department of Commerce, NOAA Tech Memo NMFS, NOAA-TM-NMFS-SWFC-42, Honolulu, HI

Alcorn DJ, Buelna EK (1989) The Hawaiian monk seal on Laysan Island: 1983. US Department of Commerce, NOAA Tech Memo NMFS, NOAA-TM-NMFS-SWFC-124

Atkinson S, Becker BL, Johanos TC, Pietraszek JR, Khun BC (1994) Reproductive morphology and status of female Hawaiian monk seals (Monachus schauinslandi) fatally injured by adult male seals. J Reprod Fertil 100:225-230

Baker JD, Thompson PM (2007) Temporal and spatial variation in age-specific survival rates of a long-lived mammal, the Hawaiian monk seal. Proc Biol Sci 274:407-415

Baker JD, Harting AL, Johanos TC (2006) Use of discovery curves to assess abundance of Hawaiian monk seals. Mar Mamm Sci 22:847-861

Banish LD, Gilmartin WG (1992) Pathological findings in the Hawaiian monk seal. J Wildl Dis 28:428-434

> Boness DJ, Bowen WD, Iverson SJ (1995) Does male harassment of females contribute to reproductive synchrony in the grey seal by affecting maternal performance? Behav Ecol Sociobiol 36:1-10

Boness DJ, Craig MP, Honigman L, Austin S (1998) Fostering behavior and the effect of female density in Hawaiian monk seals, Monachus schauinslandi. J Mammal 79:1060-1069

> Galimberti F, Boitani L (1999) Demography and breeding biology of a small, localized population of southern elephant seals (Mirounga leonina). Mar Mamm Sci 15:159-178

Galimberti F, Boitani L, Marzetti I (2000) Frequency and costs of harassment in southern elephant seals. Ethol Ecol Evol 12:345-365

Gilmartin WG, Eberhardt LL (1995) Status of the Hawaiian monk seal (Monachus schauinslandi) population. Can J Zool 73:1185-1190

Gilmartin WG, Delong RL, Smith AW, Griner LA, Dailey MD (1980) An investigation into unusual mortality in the Hawaiian monk seal, Monachus schauinslandi. In: Grigg RW, Pfund RT (eds) Proceedings of the symposium on status of resource investigations in the Northwestern Hawaiian Islands. UNIHI-SEAGRANT-MR-80-04, April 24-25, 1980, University of Hawaii, Honolulu, HI, p 32-41

> Harting AL, Baker JD, Johanos TC (2007) Reproductive patterns of the Hawaiian monk seal. Mar Mamm Sci 23:553-573

Hiruki LM, Gilmartin WG, Becker BL, Stirling I (1993a) Wounding in Hawaiian monk seals (Monachus schauinslandi). Can J Zool 71:458-468

Hiruki LM, Stirling I, Gilmartin WG, Johanos TC, Becker BL (1993b) Significance of wounding to female reproductive success in Hawaiian monk seals (Monachus schauinslandi) on Laysan Island. Can J Zool 71:469-474

IUCN (2010) IUCN Red List of threatened species. Version 2010.1. www.iucnredlist.org (accessed 31 March 2010)

Johanos TC, Austin SL (1988) The Hawaiian monk seal population structure, reproduction, and survival on Laysan Island, 1985. US Department of Commerce, NOAA Tech Memo NMFS, NOAA-TM-NMFS-SWFC-118, Honolulu, $\mathrm{HI}$

Johanos TC, Kam AKH (1986) The Hawaiian monk seal on

Editorial responsibility: Wayne Linklater,

Wellington, New Zealand
Lisianski Island: 1983. US Department of Commerce, NOAA Technical Memorandum NMFS, NOAA-TMNMFS-SWFC-58, Honolulu, HI

Johanos TC, Kam AKH, Forsyth RG (1987) The Hawaiian monk seal on Laysan Island: 1984. US Department of Commerce, NOAA Tech Memo NMFS, NOAA-TMNMFS-SWFC-70, Honolulu, HI

Johanos TCB, Becker BL, Brown ML, Choy BK, Hiruki LM, Brainard RE, Westlake RL (1990) The Hawaiian monk seal on Laysan Island, 1988. US Department of Commerce, NOAA Tech Memo NMFS, NOAA-TM-NMFS-SWFC151, Honolulu, HI

Johanos TC, Becker BL, Ragen TJ (1994) Annual reproductive cycle of the female Hawaiian monk seal (Monachus schauinslandi). Mar Mamm Sci 10:13-30

Johnson BW, Johnson PA (1978) Observations of the Hawaiian monk seal on Laysan Island: 1977. US Department of Commerce, National Technical Information Service, No. PB-285-428

Johnson BW, Johnson PA (1981a) The Hawaiian monk seal on Laysan Island: 1978. US Department of Commerce, National Technical Information Service, Springfield, VA. PB-285-428

Johnson BW, Johnson PA (1981b) Estimating the Hawaiian monk seal population on Laysan Island. US Department of Commerce, National Technical Information Service, Springfield, VA, PB-82-106113

Johnson BW, Johnson PA (1984) Observations of the Hawaiian monk seal on Laysan Island from 1977 through 1980. US Department of Commerce, NOAA Tech Memo NMFS, NOAA-TM-NMFS-SWFC-49, Honolulu, HI

Le Boeuf BJ, Mesnick S (1991) Sexual behavior of male northern elephant seals: lethal injuries to adult females. Behaviour 116:143-159

Le Galliard JF, Fitze FS, Ferriere R, Clobert J (2005) Sex ratio bias, male aggression, and population collapse in lizards. Proc Natl Acad Sci USA 102:18231-18236

Linklater WL, Cameron EZ, Minot EO, Stanfford KJ (1999) Stallion harassment and the mating system of horses. Anim Behav 58:295-306

McCowan B, Anderson K, Heagarty A, Cameron A (2008) Utility of social network analysis for primate behavioral management and well-being. Appl Anim Behav Sci 109: 396-405

National Marine Fisheries Service (2007) Recovery plan for the Hawaiian monk seal (Monachus schauinslandi), 2nd edn (revised). National Marine Fisheries Service, Silver Spring, MD

Starfield AM, Roth JD, Ralls K (1995) 'Mobbing' in Hawaiian monk seals (Monachus schauinslandi): the value of simulation modeling in the absence of apparently crucial data. Conserv Biol 9:166-174

Steifetten O, Dale S (2006) Viability of an endangered population of ortolan buntings: the effect of a skewed operational sex ratio. Biol Conserv 132:88-97

Westlake RL, Gilmartin WG (1990) Hawaiian monk seal pupping locations in the Northwestern Hawaiian Islands. Pac Sci 44:366-383

Wirtz WO II (1968) Reproduction, growth and development, and juvenile mortality in the Hawaiian monk seal. J Mammal 49:229-238

Submitted: June 20, 2008; Accepted: November 20, 2009

Proofs received from author(s): March 26, 2010 